\title{
踵なしスリッパの着用が歩行に及ぼす影響
}

\section{Influence of wearing heel-free slippers on walking}

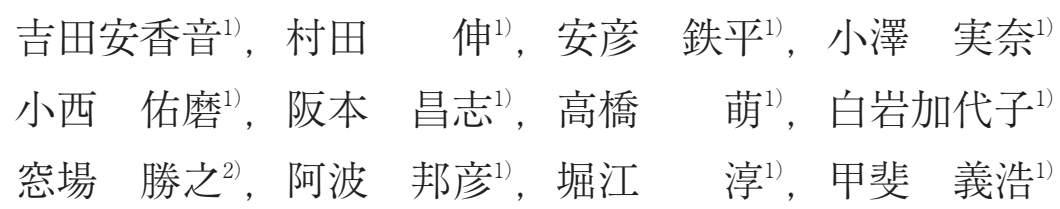

Akane Yoshida", Shin Murata", Teppei Abiko", Mina Kozawa"

Yuma Konishi", Masashi Sakamoto", Moe Takahashi", Kayoko Shiraiwa"

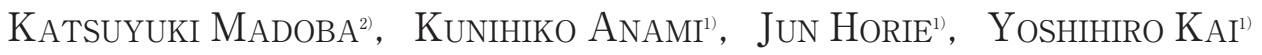

要旨：本研究の目的は，踵なしスリッパの着用が歩行に及ぼす影響を明らかにすることで ある。対象は，健常成人女性14名とした。方法は，通常のスリッパと踵なしスリッパを着 用した歩行中の歩行パラメーターと筋活動を歩行分析装置及び表面筋電計を用いて計測し た。その結果, 踵なしスリッパ歩行が通常のスリッパ歩行に比べて, 歩幅, ストライド長, 両脚支持時間が有意に短縮した。ただし，立脚時間，遊脚時間，歩行速度，ケイデンスに 有意な変化は認められなかった。筋活動では, 立脚期の大腿直筋と腓腹筋の筋活動が有意 に増大したが，立脚期の大腿二頭筋，前脛骨筋，および遊脚期のすべての筋活動に有意差 は認められなかった。以上のことから，踵なしスリッパの着用は，歩幅を狭めるが素早く 1 歩を出すことで通常のスリッパと同じ歩行速度を保ち, 大腿直筋および腓腹筋の筋活動 を効果的に高める可能性が示された。

キーワード：踵なしスリッパ，歩行パラメーター，筋活動

Abstract: This study aimed to clarify the influence of wearing heel-free slippers on walking. A total of 14 healthy women participated as subjects in this study. Using a walking analysis devise and surface electromyography, the walking parameters and muscle activities were compared between wearing normal and heel-free slippers. As a result, the step length, stride length, and double stance time were significantly shorter for heel-free than normal slippers. However, no significant difference was noted in the stance time, swing time, walking speed, or cadence. Concerning muscle activity, when using heel-free slippers, the activity of rectus femoris and gastrocnemius muscles significantly increased during the stance phase; however, no significant difference was noted in the activity of the biceps femoris or tibialis anterior muscle, nor in any muscle activity during the swing phase. Our findings suggest that wearing heel-free slippers is associated with a shorter step length, but facilitates the same walking speed as normal slippers by stepping quickly, due to which the activity of rectus femoris and gastrocnemius muscles may increase effectively.

Key words: heel-free slippers, walking parameters, muscle activities

受付日：2015年 7 月 8 日, 採択日：2015年 8 月10日

1) 京都㰌大学健康科学部理学療法学科

京都府京都市山科区大宅山田34（†607-8175）TEL075-571-1111 E-mail：murata-s@tachibana-u.ac.ip.

Department of Physical Therapy, Faculty of Health Science, Kyoto Tachibana University

2) 社会福祉法人京都博愛会病院リハビリテーション科

Department of Rehabilitation, Kyoto Hakuaikai Hospital 


\section{I 、はじめに}

我が国の要介護者数は，平成25年 3 月末時点で561 万人であり, 高齢化の進展に伴って, この数は増加し ている1”。厚生労働省による要支援または要介護状態 となった原因を調査した報告では，脳血管障害，心疾 患，がんや糖尿病といった生活習慣病を原因とするも のが30\%を超えている ${ }^{2)}$ 。生活習慣病は下肢筋量と関 係があるとされ，下肢筋量比が低いとインスリン抵抗 性，心血管疾患の危険因子が増加すると報告されてい る3)。また下肢筋のポンプ作用は, 静脈還流を増加さ せ，血流のうっ滞を改善するだけではなく，様々な血 管作動性物質を産生・活性化させ，抗凝固作用や線維 素溶解作用を発揮することが明らかにされている4)。

このように，下肢筋量と下肢筋ポンプ作用の重要性か ら，糖尿病や高血圧等の生活習慣病の予防の 1 つとし て, 下肢筋力の維持・増強およびトレーニングが重要 と考える。

近年では，下肢筋の機能維持・向上を目指すために， ストレッチ器具や下肢筋力増強器具のような多様性の ある健康器具を日常生活で使用することも多い。下肢 の筋力維持および強化を実行するための履物の一つに, 踵のない靴（踵なし靴）が挙げられ，若年者または高 齢者の間で多く利用されている。

踵なし靴は，下肢筋力や体幹筋力の増大に効果があ り, 約 2 ヶ月間着用寸ると, 腹筋，背筋，殿筋，大腿 四頭筋などの筋幅の増大に効果があることが報告され ている5)。また，踵なし靴を着用した歩行では，足関 節周囲筋よりも大腿周囲筋の筋活動の増加が認められ, 長期着用によって筋量の増加が期待できる ${ }^{6)}$ 。さらに, 体幹・下肢筋量の増大だけでなく，腹部皮下脂肪や内 臓脂肪が減少することも報告されている7)。

踵なし靴が屋外で利用されるのに対して，室内では 踵のないスリッパ（踵なしスリッパ）が利用されてい る。踵なしスリッパの使用前後を比較した研究では, 11週間の使用で腹部及び内臓の全周の横断面積の減少, 及び肥満の改善・脊柱起立筋群等の筋力増強に有用で あることが示されている8)。このように先行研究では, 踵なしスリッパの使用前と使用後の筋量の相違を報告 しているが, 歩行中の下肢筋活動や歩行パラメーター を同時に比較検討した報告は見当たらない。

そこで本研究は，健常成人を対象に，踵なしスリッ パ歩行と通常のスリッパ歩行（スリッパ歩行）の 2 種 類の条件で, 歩行パラメーターと下肢筋活動量を比較 し，踵なしスリッパ着用での歩行が歩行能力にもたら
す効果を検討した。

\section{II. 対象と方法}

\section{1. 対象者}

対象は, K大学理学療法学科に所属する健常女性 14 名で, 対象者の平均年齢は20.1 $1 \pm 1.1$ 歳, 平均体重は $49.5 \pm 3.7 \mathrm{~kg}$ ，平均身長は $158.0 \pm 5.5 \mathrm{~cm}$ であった。各 対象者には研究の趣旨と内容について説明を行い，理 解を得た上で協力を求めた。また, 研究への参加は自 由意志であることを口頭で説明し，参加同意を得た上 で研究を実施した。

\section{2. 方 法}

踵なしスリッパ歩行とスリッパ歩行の 2 条件におけ る 1 歩行周期の歩行パラメーターと下肢の筋活動量を 測定した。測定する 4 筋に表面筋電を貼付し，各筋の 最大随意等尺性収縮 (maximum voluntary contraction：MVC）時の筋活動量を測定した後に, 歩行パ ラメーターの計測を行った。それぞれの異なる歩行様 式においては，普段通り歩くように口頭にて指示した。

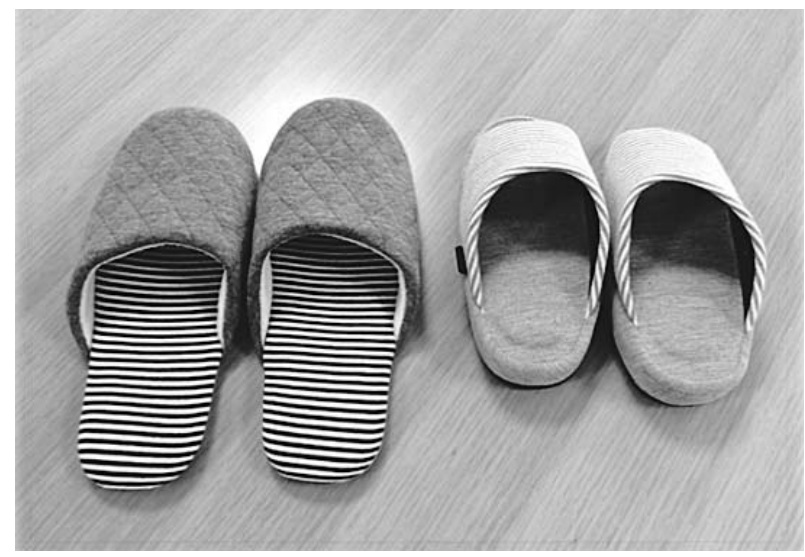

図 1 通常のスリッパ（左）と踵なしスリッパ（右）

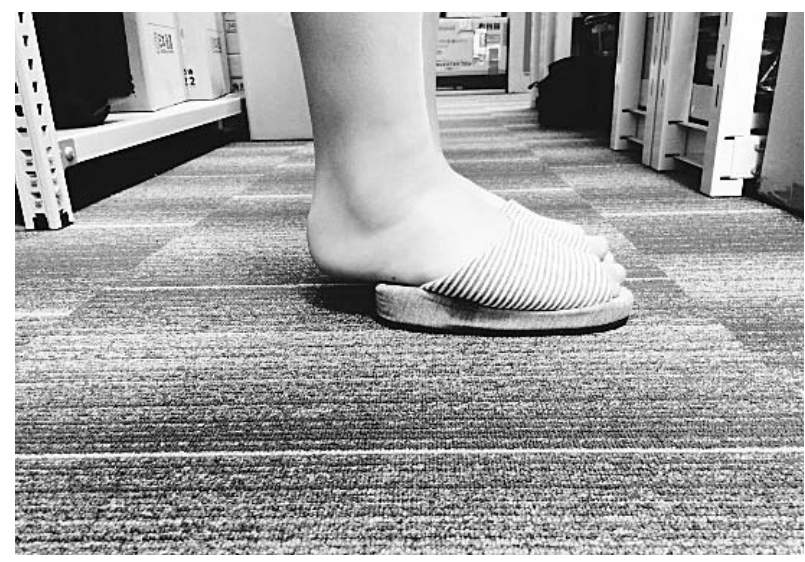

図 2 踵なしスリッパ 
なお，使用した踵なしスリッパと踵のある通常のス リッパは，ホームセンターなどで市販されている一般 的な物を使用した（図 1，2）。踵なしスリッパのサ イズは, 幅 $8.5 \mathrm{~cm}$, 長さ $18.5 \mathrm{~cm}$, 踵部の厚さ $3.5 \mathrm{~cm}$ で, 踵部が十分に出る大きさのものとした。

1) 歩行パラメーターの測定

歩行パラメーターの測定には, OPTOGAIT 光学式 歩行分析装置（MICROGAIT 社）を使用した。OPTOGAIT は, 床面から $3 \mathrm{~mm}$ の高さで10mmごとに高感度光 学センサーが配置されており, 左右に並べた 2 本 1 対 のセンサーバー間を歩行する。また，歩行路は $8 \mathrm{~m}$ と し, 加速路と減速路として歩行路の前後 $2 \mathrm{~m}$ 地点をそ れぞれ設け，測定区間は加速路と減速路を除外した 4 $\mathrm{m}$ とした（図 3 )。本装置は, 歩行解析に必須な評価 項目である立脚時間 $(\mathrm{sec})$, 遊脚時間 $(\mathrm{sec})$, 両脚支 持時間 $(\mathrm{sec})$ の時間因子や, 歩幅 $(\mathrm{cm})$, ストライド 長 $(\mathrm{cm})$ などの距離因子, 歩行速度 $(\mathrm{m} / \mathrm{sec})$, ケイ デンス (steps $/ \mathrm{min}$ )を収集するシステムであり,こ れらの歩行パラメーターを分析対象とした。

2 ）筋活動量の測定

下肢筋活動量の測定には，表面筋電計テレマイオ $\mathrm{G}$ 2 (Noraxson 社製，米国）を使用し，サンプリング 周波数は1,000Hzに設定した。測定筋は, 表在筋の中 で歩行動作に関与すると考えられる，足関節および膝 関節・股関節の単関節筋，二関節筋である右足の大腿 直筋，大腿二頭筋長頭，前脛骨筋，腓腹筋内側頭の計 4 筋とし, Perottoの記述 ${ }^{9}$ に準じて表面電極を貼付 した。なお，不感電極は腸脛勒帯に貼付し，電極間距 離は $2 \mathrm{~cm}$ とした。

測定は，まず各筋の MVC 時の筋活動を測定し，次 いで歩行時の筋活動を測定した。大腿直筋，大腿二頭 筋長頭，前脛骨筋の測定肢位については，加藤ら ${ }^{10)} の$ 方法に準じ, 対象者を端座位, 膝関節90度屈曲位とし

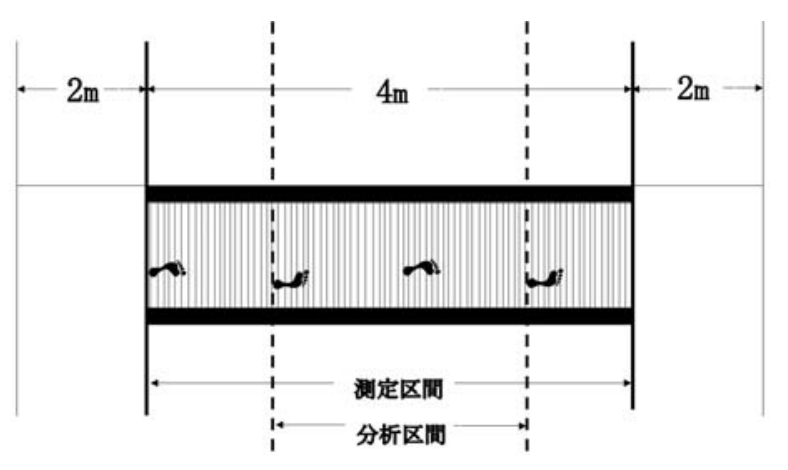

図 3 歩行パラメーターの測定 (OPTOGAIT)
た。抵抗の位置は，大腿直筋は下腿遠位部前面，大腿 二頭筋は下腿近位部後面, 前脛骨筋は足背部とし, 徒 手抵抗によって MVC を測定した。また腓腹筋の筋力 は，対象者の右片脚爪先立ちでの最大底屈位で測定し た。

筋電信号の導出には，解析ソフト（Noraxson 社製， MyoResearch XP）を用い，20-500Hzの带域通過フィ ルターを適応して，あらかじめ筋電信号からノイズを 除去した。導出された筋電信号は, 全波整流処理を行っ た後，フットスイッチおよび床反力のデータをもとに 右下肢の立脚期と遊脚期の各相に分け，一歩行周期を 100\%とした時間正規化を行い，積分筋電 (Integrated Electromyogram : IEMG) を求めた。次に, 得られ た立脚相および遊脚相の IEMGを，各筋の MVC 時 の IEMG で正規化し，\%IEMG とした。なお，MVC 時の積分筋電は MVC 時の 3 秒間において, 前後 1 秒 の 2 秒間を除いた中間 1 秒間とした。

\section{3. 統計処理}

踵なしスリッパ歩行とスリッパ歩行の各歩行パラ メーター（立脚時間，遊脚時間，両脚支持時間，歩幅， ストライド長，歩行速度，ケイデンス）および筋活動 （大腿直筋，大腿二頭筋長頭，前脛骨筋，腓腹筋内側 頭）の比較には，対応のある $\mathrm{t}$ 検定で解析した。なお， 解析には SAS 社製 Stat View（Ver 5.0）を用い，有 意水準を $5 \%$ とした。

\section{III. 結 果}

実施した踵なしスリッパ歩行とスリッパ歩行での歩 行パラメーターと下肢筋活動の結果を表 1 と表 2 に示 す。踵なしスリッパ歩行の両脚支持時間（平均土標準

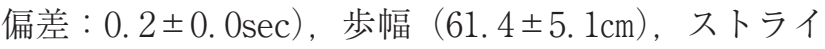
ド長 $(125.6 \pm 9.5 \mathrm{~cm})$ は，スリッパ歩行（各々 $0.3 \pm$ $0.1 \mathrm{sec}, 66.1 \pm 4.0 \mathrm{~cm}, 132.8 \pm 7.9 \mathrm{~cm})$ よりも有意に 短縮した（ $\mathrm{p}<0.01 ）$ 。また, 踵なしスリッパ歩行の 立脚期の大腿直筋 $(17.0 \pm 0.1 \%)$, 腓腹筋 $(89.0 \pm$ $0.4 \%$ ）は，スリッパ歩行（各々 $10.7 \pm 0.1 \%, 52.4 \pm$ $0.2 \%)$ よりも有意に増大した $(\mathrm{p}<0.05$ 及び $\mathrm{p}<0.01)$ 。 なお，立脚時間，遊脚時間，歩行速度，ケイデンスお よび遊脚期の筋活動には有意差が認められなかった。

\section{IV. 考 察}

本研究は, 踵なしスリッパ歩行とスリッパ歩行の歩 行パラメーターと下肢筋活動を比較することで，踵な 
表 1 スリッパ歩行と踵なしスリッパ歩行の歩行パラメーターの比較

\begin{tabular}{lccc}
\hline & スリッパ歩行 & 踵なしスリッパ歩行 & 有意確率 \\
\hline 立脚時間 $(\mathrm{sec})$ & $0.7 \pm 0.1$ & $0.6 \pm 0.1$ & $\mathrm{~ns}$ \\
遊脚時間 $(\mathrm{sec})$ & $0.4 \pm 0.0$ & $0.4 \pm 0.1$ & $\mathrm{~ns}$ \\
両脚支持時間 $(\mathrm{sec})$ & $0.3 \pm 0.1$ & $0.2 \pm 0.0$ & $\mathrm{p}<0.01$ \\
歩幅 $(\mathrm{cm})$ & $66.1 \pm 4.0$ & $61.4 \pm 5.1$ & $\mathrm{p}<0.01$ \\
ストライド長 $(\mathrm{cm})$ & $132.8 \pm 7.9$ & $125.6 \pm 9.5$ & $\mathrm{p}<0.01$ \\
歩行速度 $(\mathrm{m} / \mathrm{sec})$ & $1.3 \pm 0.2$ & $1.2 \pm 0.2$ & $\mathrm{~ns}$ \\
ケイデンス $(\mathrm{steps} / \mathrm{min})$ & $58.8 \pm 4.4$ & $59.0 \pm 7.3$ & $\mathrm{~ns}$ \\
\hline
\end{tabular}

平均土標準偏差

ns : not significant

表 2 スリッパ歩行と踵なしスリッパ歩行の下肢筋活動（\%IEMG）の比較

\begin{tabular}{llccc}
\hline & \multicolumn{1}{c}{ スリッパ歩行 } & 踵なしスリッパ歩行 & 有意確率 \\
\hline \multirow{4}{*}{ 立脚期 } & 大腿直筋 & $10.7 \pm 0.1$ & $17.0 \pm 0.1$ & $\mathrm{p}<0.05$ \\
& 大腿二頭筋 & $30.4 \pm 0.2$ & $35.4 \pm 0.3$ & $\mathrm{~ns}$ \\
& 前脛骨筋 & $20.4 \pm 0.1$ & $20.2 \pm 0.1$ & $\mathrm{~ns}$ \\
& 腓腹筋 & $52.4 \pm 0.2$ & $89.0 \pm 0.4$ & $\mathrm{p}<0.01$ \\
\hline \multirow{2}{*}{ 遊脚期 } & 大腿直筋 & $7.5 \pm 0.0$ & $8.6 \pm 0.0$ & $\mathrm{~ns}$ \\
& 大腿二頭筋 & $18.4 \pm 0.1$ & $20.7 \pm 0.2$ & $\mathrm{~ns}$ \\
& 前脛骨筋 & $23.9 \pm 0.1$ & $23.5 \pm 0.1$ & $\mathrm{~ns}$ \\
& 腓腹筋 & $21.0 \pm 0.2$ & $27.7 \pm 0.2$ & $\mathrm{~ns}$ \\
\hline
\end{tabular}

平均土標準偏差 $(\%)$

ns : not significant

しスリッパ着用が筋活動や歩行能力に与える効果につ いて検討した。その結果, 踵なしスリッパ歩行の両脚 支持時間，歩幅，ストライド長は，スリッパ歩行より も有意に短縮していた。筋活動においては, 踵なしス リッパ歩行での立脚期の大腿直筋, および腓腹筋が有 意に増大していた。これらのことから, 踵なしスリッ パ歩行の特徵として歩幅が狭いことが挙げられ， ス リッパ歩行と同じ歩行速度を保ち, 立脚期において大 腿直筋および腓腹筋の筋活動を増大させる履物である ことが示唆された。

踵なしスリッパは, 図1に示したようにスリッパの 踵部をカットしているため, 歩行において前足部接地 になりやすいのが特徴であり, 踵接地が出来ずヒール ロッカー機能11 が作用しない履物である。ヒールロッ カー機能は, 踵骨隆起の表面での床接地によって, 下 肢の推進力として作用する。また, 立脚側の荷重の受 け継ぎは，踵からの初期接地によって行われる。すな わち，この機能が久如した踵なしスリッパ歩行では, 推進力の産生が不十分となるため下腿の前進が容易に 行えずに, スリッパ歩行と比べて歩幅やストライド長 が短縮したものと考えられる。
また, 踵なしスリッパは, 歩行時における足底の接 地面積が狭いことが特徵である。静止立位における足 部での体重支持は, 踵骨と第 1 および第 5 中足骨頭が 主要な荷重点となる ${ }^{12)}$ 。体重は, 左右の下肢にほほ均 等に荷重が加わるため, 脛骨から距骨への荷重は体重 の50\%である。距骨はこれを踵骨に $25 \%$ ，母趾球と小 趾球とを併せて $25 \%$ の比率で分配している ${ }^{13)}$ 。そのた め, 踵部が欠如した踵なしスリッパ歩行は, より多く の荷重が前足部に加わるため, 重心が前足部に偏位し， 相対的に前後方向の重心移動距離が短くなる。このこ とから，身体重心を支持基底面内に保持し，同時に目 的とする運動方向へ変化させる結果として ${ }^{14)}$, 両脚支 持時間を短縮させて素早く一歩を踏み出したと推察し た。両脚支持時間の短縮は, 歩行速度を速める要因と なるが，本研究では歩行速度に有意差を認めなかった。 それは, 踵なしスリッパ歩行の歩幅とストライド長が 短縮したために, 両脚支持時間の短縮の影響が相殺さ れたものと考えられる。以上のことから，健常成人に おいて踵なしスリッパ歩行は, 歩幅を狭めるが素早く 1歩を出すことで, スリッパ歩行と同じ歩行速度を保 てる履物であることが示唆された。 
歩行中の筋活動について，スリッパ歩行よりも踵な しスリッパ歩行の方が，立脚期における大腿直筋と腓 腹筋の筋活動量が有意に上昇した。前述したように, 踵なしスリッパ歩行は踵部の欠如によって前足部接地 となりやすい。足底圧の中心位置が前足部へ移動する ことにより，前足部での床反力は増大し，足関節には 背屈方向へのモーメントが発生する ${ }^{15)}$ 。そのため歩行 時では，足関節背屈モーメントに拮抗した筋活動が認 められるため, 強力な底屈筋である腓腹筋の筋活動が 高まり, 一方で背屈筋である前脛骨筋には有意な変化 は認められなかったと推察した。なお，踵なしスリッ パ歩行は踵部の欠如により，爪先立ちとなった立脚期 に筋活動の増大を認めやすく，遊脚期には影響しにく いことが示唆された。

また，踵なしスリッパ歩行では立脚期の前足部荷重 移行により，足部背屈の外的モーメントが発生してい るため, 足関節背屈に伴って下腿が前傾し膝関節は屈 曲位となりやすい。そのため, 二関節筋である大腿直 筋の遠心性収縮がスリッパ歩行よりも増大したと推察 された。

これらの知見から，健常成人に抢いて踵なしスリッ パ歩行は，スリッパ歩行と同じ歩行速度を保ちながら， かつ大腿直筋および腓腹筋の筋活動を効果的に増大さ せるなど，健康用具として一定の効果がある可能性が 示された。ただし本研究は，若年者を対象に行った研 究であり，転倒の危険性がある高齢者には不安定な履 物と予測される。そのため，踵なしスリッパ歩行が本 研究と同様の効果を得るとは限らないことから，健常 高齢者を対象にした検討をする必要がある。

\section{引用文献}

1) 厚生労働省：平成24年度 介護保険事業状況報告（年報） のポイント

http://www.mhlw.go.jp/topics/kaigo/osirase/jigyo/12/dl/ h24_point.pdf（2015年 3 月 1 日現在）

2 ) 厚生労働省：平成22年（2010）度介護の状況. http://www.mhlw.go.jp/toukei/saikin/hw/k-tyosa/k-tyosa 10/4-2.html（2015年 3 月 1 日現在）

3 ) 田尻祐司, 山田研太郎：2 型糖尿病患者に抢ける体組成の 特徵とインスリン抵抗性および心血管危険因子との関連. 日本体質医学会雑誌，2011，73(1)：1 - 5 .

4 ）冷水陽子，阿久根和恵，浜田和美 - 他：下肢深部静脈血栓 症予防に対する間歇的下肢加圧装置の有用性. 日本手術医 学会誌, 2001，22(1)：28-31.

5 ) 松浦義和：踵なし靴(解説／特集)。整形・災害外科，2003, 46(12) : 1431-1440.

6 ）塚本いね子, 西尾瞳, 青木主税：踵なし靴が歩行に与える
影響踵なし靴着用時と運動靴着用時での比較. 北里理学療 法学, 2002, (5)：85-88.

7 ）松浦義和：高齢者用踵なし靴について。靴の医学, 2001, 14(2) : 35-40.

8 ）松浦義和：踵なしスリッパが肥満および金柱起立筋に及ぼ す影響について。靴の医学, 1998，11：75-79.

9) Perotto AO (著), 相森 良 (訳)：筋電図のための解剖 ガイド 第三版。西村書店, 新潟, 2003， 132-191.

10）加藤宗規，山崎裕司，柊幸伸・他：ハンドヘルドダイナモ メーターによる等尺性膝伸展地域在住高齢者の各種歩行パ ラメータに関連する要因分析筋力の測定固定用ベルトの使 用が検者間再現性に与える影響。総合リハビリテーション 2001, 29(11)：104-1050.

11) Perry J : ペリー歩行分析 正常歩行と異常歩行. 医歯薬出 版, 東京, 2007, 59 .

12) Gardner E, Gray D, O'Rahilly R: A Regional Study of Human Structure. In: W. B, Saunders (Ed), Anatomy. Philadelphia 1971, 263.

13）中村隆一, 齋藤宏, 長崎浩：基礎運動学 第 6 版. 医歯薬 出版, 東京, 2003, 318-320.

14）桐山希一：足底圧の動的変化を指標とした健常成人の歩行 制御扮よび片麻痺歩行に関する研究. 医療保健学研究. 2012. (3) : 1 - 40

15）山口剛司, 高崎恭輔, 大工谷新一：足底圧中心変化に伴う 足部周囲筋の筋積分值相対值変化，関西理学，2005，5 : 103-108. 